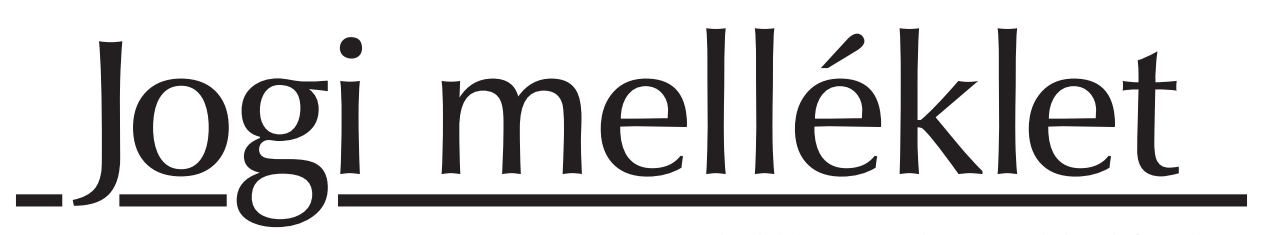

Külgazdaság, LXI. évf., 2017. március-április (24-51 o.)

\title{
A nemzetközi szerződésekre alkalmazandó jog meghatározása, különös tekintettel a Róma I. rendelet alkalmazási körére és a jogválasztásra
} SZABÓ SAROLTA

A Róma I. rendelet a szerződéses kötelezettségekre alkalmazandó jog meghatározásáról az ún. Római Egyezmény szabályain alapul és annak rendelkezéseit váltja fel, igy az a 2009. december 17-ét követôen kötött szerzödésekre irányadó. A tanulmány elsőként a Róma I. rendelet hatályának komplex szabályozását mutatja be az Európai Unió Bíróságának legújabb itéletei tükrében. Másodikként pedig a rendelet 3. cikkében lefektetett jogválasztás szabályait elemzi összevetve azokat a magyar Kódex és a készülö nemzetközi magánjogitörvény-tervezet rendelkezéseivel.

Journal of Economic Literature (JEL) kód: K12 - Contract Law.

A nemzetközi szerződések a XXI. században szinte észrevétlenül hálózzák be mindennapi életünket. Gondoljunk csak a társaságok közötti rendszeres és gyakori adásvételi ügyletekre, mondjuk: ha egy magyar cég egy külföldi társaság honlapján keresztül tartós szerződés keretében külföldről vásárol autóalkatrészeket, ${ }^{1}$ avagy ha a romániai üzleti partnerétől egy magyar cég tenyésztojásokat rendel. ${ }^{2}$ Ezen ügyletek a ,jog világában” általában egészen addig „láthatatlanok” maradnak, ameddig mindkét fél megtalálja a számítását. Probléma akkor adódik, ha a fenti eseteket véve

${ }^{1}$ Fővárosi Ítélőtábla 14.Gf.40.333/2015/5/II.

2 Fővárosi Îtélőtábla 14.Gf.40.318/2014/4/II.

https://doi.org/10.47630/KULG.2017.61.3-4.24

Szabó Sarolta PhD, egyetemi docens (PPKE JÁK Nemzetközi Magánjogi Tanszék). E-mail: szabo.sarolta@jak.ppke.hu.

24 JOGI MELLÉKLET • 2017/3-4 
A nemzetközi szerződésekre alkalmazandó jog meghatározása, különös...

alapul: pl. a vevő egy másik cégtől olcsóbban tudja beszerezni az autóalkatrészeket, avagy Romániában megjelenik a H5N1 vírus, így ideiglenesen betiltják az élő baromfi szállitását és értékesítését.

\section{Röviden az egységesített anyagi jogról}

A fentebb hozott ügyek nemzetközi adásvételi szerződésnek tekinthetőek, amely mind a mai napig a nemzetközi kereskedelemben leggyakoribb ügyletei. Nem véletlen tehát, hogy e területen már a XX. század elején megindult a jogegységesítés (unifikáció). Az egységes adásvételi jog „megteremtésének” története 1929-hez kapcsolható, amikor Ernst Rabel az UNIDROIT (Nemzetközi Intézet a Magánjog Egységesítésére) igazgatótanácsának tagjaként javaslatot tett az áruk adásvételi jogának unifikálására. ${ }^{3}$ A javaslat elfogadását követően - évtizedek múlva - az 1964-ben Hágába összehívott diplomáciai konferencián, végül két egyezmény került elfogadásra: az Egységes Törvény az áruk nemzetközi adásvételéröl (Uniform Law on the International Sale of Goods, ULIS) és az Egységes Törvény az áruk nemzetközi adásvételi szerződéseinek megkötéséröl (Uniform Law on the Formation of Contracts for the International Sale of Goods, ULFIS). A Hágai Egységes Törvények azonban nem voltak túl sikeresek - az államok nem csatlakoztak hozzá -, ezért 1966-ban a munka újra kezdődött az UNCITRAL (ENSZ Kereskedelmi és Jogi Bizottsága) keretén belül, amelynek eredményeként 1980-ban megszületett Az áruk nemzetközi adásvételi szerzödéseiről szóló ENSZ-egyezmény (United Nations Convention on Contracts for the International Sale of Goods - CISG; Bécsi Konvenció). Mindazon kereskedők vonatkozásában, amelyeknek ,üzleti helye” a Konvencióhoz csatlakozott különböző államok területén található (jelenleg 85 állam; pl. Ausztria, Románia, Magyarország) - a nemzetközi magánjogszabályokat „beelőzve” -, ún. autonóm módon alkalmazandó a Konvenció. Főszabály szerint tehát mind az autóalkatrészek, mind a tenyésztojások adásvétele egy nemzetközileg unifikált anyagi jogi egyez-

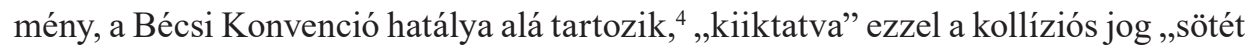
ingoványát", 5 és egyben megelőzve ezáltal a hazai, belső jogi (Ptk.) rendelkezéseket is.

${ }^{3}$ Bővebben pl.: Bánrévy [2016], 102-103. o.; Szabó [2014], 17. o.

${ }^{4}$ Bővebben a legújabb magyar gyakorlatról, pl.: Glavanits [2016]; Vadász [2017].

5 Ahogy a nemzetközi magánjog egy amerikai egyetem dékánja az 1950-es években nevezte. Prosser, W. [1953]: Interstate Publication. Michigen Law Review. Hivatkozza: Herzog [1992], 249. o. 
Azonban tekintettel arra, hogy a Konvencióval egységesített szerződési anyagi joghoz nem minden állam csatlakozott, valamint - mivel az egyezmények megszületése mindig kompromisszumok eredménye - az nem szabályozhat minden szerződési joggal kapcsolatos kérdést, harmadsoron pedig a felek akár ki is zárhatják a Konvenció alkalmazását, ezért a nemzetközi szerződési jog kollíziós (azaz az alkalmazandó jogot kijelölő) szabályaira továbbra is szükség van.

\section{Nemzetközi szerződések kollíziós szabályozása}

\subsection{Jogforrások}

A szerződések kollíziós egységesítése a XX. században, kezdetben a - bilaterális jogsegélyegyezmények mellett - multilaterális nemzetközi egyezmények útján történt. Ennek kidolgozásában a Hágai Nemzetközi Magánjogi Konferencia (Conférence de la Haye de Droit International Privé/Hague Conference on Private International $\mathrm{Law}-\mathrm{HccH}$ ) játszott föszerepet, megalkotva:

- az 1955. évi, az ingó dolgok nemzetközi adásvételére alkalmazandó jogról szóló egyezményt, amelyet 1985-ben ugyan modernizáltak, ez utóbbi azonban mégsem lépett hatályba;

- az 1978. évi, a képviseleti szerződésekre alkalmazandó jogról szóló egyezményt (nem lépett hatályba).

Megjegyzendő a Hágai Nemzetközi Magánjogi Konferencia által 2015-ben közzétett újabb instrumentum (amely nem nemzetközi egyezmény): a jogválasztásnak a nemzetközi kereskedelmi szerződésekben érvényesülő alapelveiröl (Hague Principles of Choice of Law in International Commercial Contracts). ${ }^{6}$ Ez az alapelvek tulajdonképpen mintául szolgál azoknak az államoknak a számára, amelyek nemzetközi magánjogában a kereskedelmi szerződéseknél nem engedik a felek akarati autonómiájának érvényesülését (egyes latin-amerikai országok), valamint azoknak az államoknak a számára is, akik ezt már lehetővé teszik, a meglévő rendelkezéseik finomítására, modernizálására (pl. a jogválasztás módjait és korlátait illetően).

Jelentősebb sikereket ért el a kollíziós jogot illetően a regionális jogegységesítés, azon belül is az Európai Unió. Még az Európai Gazdasági Közösségben 1967-ben a belga delegátus által került benyújtásra egy tervezet, amelyet később tagállami

\footnotetext{
${ }^{6}$ Letölthető: https://www.hcch.net/en/instruments/conventions/full-text/?cid=135
} 
A nemzetközi szerződésekre alkalmazandó jog meghatározása, különös...

szakértők, valamint a Bizottság közösen dolgoztak át. A tervezet munkálatait a polgári és kereskedelmi ügyekben a joghatóságról, valamint a határozatok elismeréséről és végrehajtásáról szóló egyezmény (Brüsszeli Egyezmény) ${ }^{7}$ sikerét követően a Bizottság vitte tovább. Az ekkor még a szerződéses és a szerződésen kívüli kötelmek alkalmazandó jogi szabályainak megalkotása 1978-ban (az Egyesült Királyság delegációjának kérésére) végül csak a szerződések jogára korlátozódott. Az 1979ben befejezett tervezetet 1980-ban az Európai Bizottság elfogadta mint a közösségi nemzetközi kolliziós magánjogi jogegységesitésének első lépését. ${ }^{8}$ Célja szerint az Egyezmény hozzájárul az alkalmazandó jog egyszerübb megtalálásához, valamint a forum shopping kiküszöböléséhez. Az Európai Közösség (EK) tehát az 1980-as Római Egyezménnyel megalkotta azt a zártkörü multilaterális nemzetközi egyezményt (ti. az egyezmény szerződő államai csak az EK tagállamai lehettek), amely így kizárólag az EK tagállamainak bíróságai és más hatóságai számára egységesen határozta meg a szerződéses kötelezettségekre alkalmazandó jogot. Az ún. Római Egyezményt - mint loi uniforme-ot - Magyarország a 2006. évi XXVIII. törvénynyel ratifikálta, és időbeli hatályát tekintve a 2006. július 1-je és 2009. december 17-e között kötött szerződésekre alkalmazandó. Az Amszterdami Szerződést követően azonban - amikor is az igazságügyi együttműködést a polgári és kereskedelmi ügyekben az ún. harmadik pillérből az első pillérbe tették át - az EK jogegységesítő tevékenysége új lendületet, ti. rendeleti és irányelvi jogalkotási lehetőségeket kapott. Ettől kezdve ugyanis a nemzetközi magánjogi tárgyú jogforrások között meghatározó szerephez jutnak a közösségi, majd az uniós rendeletek [Amszterdami Szerződéssel (1997/1999. május 1.) módosított EK-szerződés 61. cikk c) pontjában és 65. cikkében; jelenleg a Lisszaboni Szerződés (2007/2009. december 1.) óta az Európai Unió Müködéséről szóló Szerződés - EUMSz 81. cikkében biztosított kompetencia alapján]. A nemzetközi közjogi instrumentumként elfogadott Római Egyezményt ezután átalakították és pontosították, amelynek eredményeképpen az Egyezményt felváltotta az Európai Parlament és Tanács 593/2008/EK rendelete (2008. június 17.) a szerződéses kötelezettségekre alkalmazandó jogról, azaz az ún. Róma I. rendelet, ${ }^{9}$ amely a 2009. december 17-ét követően kötött szerződésekre alkalmazandó. A Róma I. rendelet sok kérdésben átveszi a Római Egyezmény rendelkezéseit, pl. a hatály,

${ }^{7}$ A polgári és kereskedelmi ügyekben a joghatóságról és a bírósági határozatok elismeréséről és végrehajtásáról szóló egyezmény (1968).

${ }^{8}$ Részletesen a megszületés körülményeiről és a részletszabályokról: Burián [2008], Burián [1992a], Burián [1992b], Szabó [2009].

9 Az Európai Parlament és a Tanács 593/2008/EK rendelete a szerződéses kötelezettségekre alkalmazandó jogról (Róma I.), HL L 177., 2008.7.4., 6-16. 
míg másokban eltérő megoldásokat követ, pl. jogválasztás hiányában irányadó jog meghatározása.

Napjainkra tehát a kötelmi jogra vonatkozó nemzetközi magánjogi szabályok az Európai Unió jogalkotói tevékenysége folytán jelentős mértékben egységesítettek. A vonatkozó joghatósági és elismerés-végrehajtási szabályok a Brüsszel I. bis rendeletben ${ }^{10}$ találhatóak, míg az alkalmazandó jogi rendelkezések a Róma I. és a Róma II. rendeletben. ${ }^{11}$ Mindhárom rendeletre igaz, hogy azokat autonóm módon (tehát saját fogalomviláguk, szabályrendszerük keretei között - azaz az uniós jog egészét és nem a tagállami jogok rendelkezéseit nézve) kell értelmezni. Az uniós jogforrások terminológiai átfedései így a fentebb felsorolt rendeletek közötti egységes értelmezést kívánnak meg az uniós kollíziós és joghatósági szabályok konzisztenciájához (bár sosem szabad elfelejteni, hogy a joghatósági és alkalmazandó jogi rendelkezések eltérő célokat szolgálhatnak). Ehhez egy további szempont a Róma I. rendelet és a Róma II. rendelet közötti szoros kapcsolat, ti. ezeket a rendeleteket egymást kiegészítő szabályozásként alkották meg az EU nemzetközi kollíziós kötelmi jogi rezsimjének egységesitésére.

\subsection{A jogforrások egymáshoz való viszonya}

Egy nemzetközi szerződésre alkalmazandó jog (lex contractus) meghatározásánál a jogalkalmazó számára a legelső akadályt a jogforrások bősége jelenti. Amenynyiben olyan polgári és kereskedelmi szerződésről van szó, amely mind a Római Egyezmény, mind a Róma I. rendelet tárgyi hatálya alá tartozik, akkor a jogforrások időbeli hatálya, azaz a szerződéskötés időpontja dönti el, hogy melyikük lesz irányadó az ügyletre. A hazai nemzetközi magánjogi tvr., a Kódex ${ }^{12}$ pedig szubszidiárius jelleggel mint mögöttes/kisegítő joganyag rendelkezik a szerződések kollíziós szabályozásáról: azaz ha a szerződést a Római Egyezmény hatályba lépése előtt kötötték, vagy olyan ügyletről van szó, amelyet az Egyezmény és a Róma I. rendelet sem von az alkalmazási körébe. Lényeges, hogy a visszaható hatály általános tilalma miatt a Kódex szerződéskötéskor hatályos szövegét kell a jogalkalmazónak figyelembe venni. Megjegyzendő, hogy a 2009. évi IX. törvénnyel a Kódexet jogharmonizációs

10 1215/2012/EU rendelete a polgári és kereskedelmi ügyekben a joghatóságról, valamint a határozatok elismeréséről és végrehajtásáról. HL L 351., 2012.12.20., 1-32.

11 Az Európai Parlament és a Tanács 864/2007/EK rendelete a szerződésen kívüli kötelmi viszonyokra alkalmazandó jogról, HL L 199., 2007.7.31., 40-49.

12 1979. évi 13. törvényerejü rendelet a nemzetközi magánjogról. 
céllal - többek között - az uniós rendeletekhez (Róma I. és II. rendelet) kívánta igazítani a jogalkotó, amely azonban nem volt minden téren sikeresnek mondható. ${ }^{13}$

Az időbeli hatály alakulása az alábbi idővonalon szemléltethető:

\begin{tabular}{|c|l|l|}
\hline \multicolumn{1}{|c|}{ Kódex } & \multicolumn{1}{|c|}{ Római Egyezmény } & \multicolumn{1}{c|}{ Róma I. rendelet } \\
$\leftrightarrow$ & $\leftrightarrow$ & $\rightarrow$ \\
\hline $\begin{array}{l}\text { 2006. július 1-je elött } \\
\text { kötött szerződésekre }\end{array}$ & $\begin{array}{l}\text { 2006. július 1-je és 2009. december } \\
\text { 17-e között kötött szerződésekre }\end{array}$ & $\begin{array}{l}\text { 2008. december 17-ét } \\
\text { követően kötött szerződésekre }\end{array}$ \\
\hline
\end{tabular}

Némiképp tovább komplikálja a helyzetet egy másik, kapcsolódó bi- vagy multilaterális nemzetközi egyezmény fennállta. Amennyiben például a Római Egyezményt kellene a magyar fórumnak alkalmazni, akkor annak rendelkezései szerint az egyezmény nem érintette azoknak a nemzetközi egyezményeknek az alkalmazását, amelyeknek valamely szerződő állam a csatlakozáskor már részese volt (20. cikk). Így a magyar-lengyel jogsegélyegyezmény vonatkozó cikke megelözi a Római Egyezmény szabályait (1960. évi 5. tvr.), tehát a szerződésre jogválasztás hiányában azon Szerződő Fél jogának alkalmazását írja elő, amelynek területén a szerződést megkötötték (45/A. §). ${ }^{14}$ Amennyiben viszont már a Róma I. rendelet időbeli hatálya alá tartozó szerződésről van szó, az említett bilaterális egyezmény azért nem alkalmazandó, mert bár főszabály szerint a rendelet is „udvarias jogforrásként”, előzékenyen elsőbbséget enged a korábban kötött nemzetközi egyezményeknek, azonban rögzíti azt is, hogy a rendelet elsőbbséget élvez a kizárólag két vagy több tagállam között megkötött egyezményekkel szemben (25. cikk).

A továbbiakban - alkalmazásának gyakorisága okán - elsősorban a Róma I. rendelet rendelkezései és gyakorlata kerül alaposabb elemzésre azzal, hogy a Római Egyezmény, a Kódex és az új törvény szabályozásának lényegesebb eltérései a vonatkozó részeknél kerülnek ismertetésre.

${ }^{13}$ Részletesen: Burián [2017], Vékás [2009].

${ }^{14}$ Burián [2014], 54. o. 
2.3.1. A Róma I. rendelet hatálya: egyetemes alkalmazás, területi, időbeli és tárgyi hatály

2.3.1.1. Egyetemes alkalmazás

Alkalmazási körét tekintve a Róma I. rendeletnek csakúgy, mint a Római Egyezménynek univerzális jellege van, azaz a rendelet szerint meghatározott jogot akkor is alkalmazni kell, ha az nem egy tagállam joga (2. cikk). Az egyetemes alkalmazás tehát azt jelenti, hogy a Róma I. rendelet szabályai irányadóak akkor is, ha a rendelet szerint kijelölt anyagi jogként nem egy EU-tagállam joga alkalmazandó. Ha tehát az összeütközés a magyar és a brazil jog között áll fenn, és a rendelet ez utóbbi alkalmazását rendeli, akkor a fórumnak a brazil jog szerint kell az ügyet megítélni, függetlenül attól, hogy a lex causae nem egy uniós tagállam joga. Ebböl következik tehát, hogy maga a rendelet nem csak az unión belüli jogviszonyokra, hanem akkor is irányadó, ha a szerződés unión kívüli külföldi elemmel vagy elemekkel bír. A rendelet szerint tagállamnak minősülő országok fórumai (lásd alább a területi hatály) a rendelet hatálya alá tartozó szerződések esetében tehát kötve vannak a Róma I. rendelet szabályaihoz. Például egy magyar bíróságnak a rendelet szerint kell meghatározni az alkalmazandó jogot egy magyar és egy brazil központi ügyvezetési helyü társaság között kötött franchise szerződés esetén. Természetesen a rendelet akkor is alkalmazandó, ha a szerződés egyes elemei kizárólag különböző EU-tagállamokhoz, sőt külföldi jog választása esetén még abban az esetben is irányadóak, ha csak egyetlen államhoz kapcsolódnak (ezt akként is megfogalmazzák, hogy a rendeletnek tehát erga omnes - azaz mindenkire kiterjedő - hatálya van). ${ }^{15}$

2.3.1.2. Területi hatály

Területi hatályát illetően a Róma I. rendelet az összes tagállamban alkalmazandó, kivéve Dániát. Tulajdonképpen az EU-tagállamok fórumai (és jogalkalmazói) számára a rendelet egységes kollíziós szabályokat ad a polgári és kereskedelmi ügyekben kötött szerződések vonatkozásában. A Róma I. rendelet 1. cikk (4) bekezdése szerint a rendelet alkalmazásában a „tagállamok” kifejezés azokat a tagállamo-

${ }^{15}$ Ragno [2015], 71. o. 
A nemzetközi szerződésekre alkalmazandó jog meghatározása, különös...

kat jelenti, amelyekre e rendelet alkalmazandó. Tekintettel arra, hogy a rendeletet az EKSz 65. cikkének (jelenleg EUMSz 81. cikk) felhatalmazása alapján fogadták el, így sem Dánia, sem az Egyesült Királyság, sem Írország nem tartozik a rendelet területi hatálya alá, ti. ezen országok az Amszterdami Szerződéssel ezen cikkek alól „kiszerződtek” (opt-out klauzula), azaz lehetőséget kaptak a távolmaradásra. Azonban az Egyesült Királyság és Írország mégis úgy döntött, hogy „beleszerződik” (opt in) a Róma I. rendeletbe, így annak szabályai e két állam esetében is alkalmazandóak. Dánia azonban nem minősül tagállamnak (és a Lisszaboni Szerződés hatályba lépéséig nem is volt lehetősége - többek között - a nemzetközi magánjogi tárgyú joganyagokhoz való csatlakozásra). A dán fórumok tehát továbbra is a - nemzetközi közjogi kötelezettségük alapján vállalt - Római Egyezmény rendelkezéseit alkalmazzák a szerződéses kötelmek kollíziós szabályaiként.

2.3.1.3. Időbeli hatály

A Róma I. rendelet 2008. július 24-én lépett hatályba, de a 2009. december 17-ét követöen kötött szerzödésekre (beleértve a december 17-ét is) alkalmazandó (28-29. cikk). Abban a kérdésben, hogy a szerződést mikor kötötték, a rendelet szerint kijelölt anyagi jogot kell alkalmazni (10. cikk). A hosszú távú vagy folyamatos szerződéses kötelmek (pl. disztribútori vagy munkaszerződés) esetében is főszabály szerint az ügyletkötés időpontja a döntő. ${ }^{16}$

Az Európai Unió Bírósága (EUB) a 2016-ban született Nikiforidis-ítéletben (C135/15. sz.) értelmezte a rendelet időbeli hatályát egy 1996-ban kötött munkaszerződés esetében, amelyet 2010-2012 között többször is módosítottak. ${ }^{17}$ Ennek kapcsán az EUB kifejtette, hogy a rendelet Bizottság által készített tervezetében szerepelt, hogy annak hatálya alá tartozzanak a 2009. december 17-e elött kötött szerződések jövőbeni joghatásai, ezt azonban az uniós jogalkotó végül kizárta. Egy ezzel ellentétes álláspont ráadásul szembemenne a jogbiztonság elvével, és különösen kedvezőtlen lenne a jogviták kimenetelének elöreláthatósága és az alkalmazandó jog bizonyossága szempontjából, amelyek a rendelet egyik céljának tekinthetők [(6) preambulum-bekezdés]. Ugyanakkor az EUB hozzátette, hogy ha egy 2009. december 17-ét megelőzően létrejött szerződésen ezen időpontot követően „olyan terjedelmü, a szerződő felek közötti megállapodás tárgyát képező módosítást hajtanának végre, amely nem az említett szerződés egyszerủ naprakésszé tételét vagy kiigazítá-

16 Omlor [2015], 510. o.

17 ECLI:EU:C:2016:774. 
sát, hanem e szerződő felek közötti új jogviszony létrehozását eredményezi”, akkor az eredeti szerződést úgy kellene tekinteni, hogy azt felváltja egy új, a Róma I. rendelet időbeli hatálya alá tartozó szerződés. ${ }^{18}$ Következésképp, a Róma I. rendelet 28. cikket akként kell értelmezni, hogy egy 2009. december 17-ét megelőzően létrejött szerződéses munkaviszony csak akkor tartozik e rendelet hatálya alá, ha e viszony a szerződő felek kölcsönös és ezen időponttól kezdődően kinyilvánított megegyezése alapján olyan terjedelmü módosításon ment keresztül, hogy azt az említett időponttól kezdődően kötött új munkaszerződésnek kell tekinteni.

2.3.1.4. Tárgyi hatály

A Róma I. rendelet pozitive és negative is meghatározza tárgyi hatályát. Pozitíve kifejezetten deklarálja, hogy a rendelet a polgári és kereskedelmi ügyekben kötött szerzödésekre alkalmazandó, „olyan helyzetekben, amikor különböző országok joga között kell választani” [1. cikk (1) bekezdés)].

Ennek alapján három általános elemet különböztethetünk meg:

a) szerződéses kötelezettség;

b) polgári és kereskedelmi ügyek;

c) kollíziós jogi helyzet fennállta.

A szerződéses kötelezettség fogalma „demarkációs vonalként” szolgál a Róma I. és a Róma II. rendelet között. Míg a Róma I. a „szerződéses kötelezettségekre”, addig a Róma II. rendelet a „szerződésen kívüli kötelezettségekre” alkalmazandó. Egy világos választóvonalhoz a fogalom egységes és autonóm értelmezése szükséges, de a rendeletek nem adnak kifejezett definíciót. Mindemellett a Róma I. rendelet világossá teszi, hogy a szerződés mint speciális minősítési kérdés vonatkozásában nem feltétel egy érvényes szerződés fennállta [a rendelet által kijelölt lex causae kiterjed pl. a szerződés érvénytelenségének meghatározására is, lásd 12. cikk (1) bekezdés e) pont]. Az Európai Bíróság is ekként értelmezte még a Római Egyezmény „,szerződés" fogalmát az Arcado-ügyben (C-9/87. sz. SPRL Arcado kontra SA Haviland). ${ }^{19}$ Ahogy azt a Róma I. rendelet (7) preambulum-bekezdésében is kimondja, a rendelet tárgyi hatályának és rendelkezéseinek összhangban kell lenniük a Brüsszel I., valamint a Róma II. rendelettel. Az EUB-nak a Brüsszel I. rendelettel kapcsolatos ítélkezési gyakorlatából kitünik, hogy kizárólag az a jogi kötelezettség tartozik a „szerződés vagy egy szerződéses igény” hatálya alá (5. cikkének 1. pontja), amelyet

18 Ítélet 37. pont.

19 van Calster [2016], 206. o. 
A nemzetközi szerződésekre alkalmazandó jog meghatározása, különös...

az egyik fél a másik felé szabadon vállalt és amelyen a felperes keresete alapul (lásd: Kolassa-ítélet, C-375/13. sz.). ${ }^{20},{ }^{21}$

Így analógia útján megállapítható, hogy a Róma I. rendelet szerinti „szerződéses kötelezettség” az egyik fél által a másik felé szabadon vállalt. ${ }^{22}$ Ezt kifejezetten kimondta az EUB az ERGO Insurance-ítéletben (C-359/14. és C-475/14. sz. egyesített ügyek). ${ }^{23}$ Ahol ez az önkéntes elem hiányzik, az a föszabály szerint szerződésen kívüli kötelezettségnek minősül, így a Róma II. rendelet hatálya alá tartozik. A szerződéses és a szerződésen kívüli kötelezettségek e kettőssége jelenik tehát meg (tertium non datur - harmadik lehetőség tehát nincs). Határesetek viszont vannak, ahol nehéz a kettőt elválasztani: pl. a nyereményígéret, vagy a szerződés megkötését megelőzően folytatott tárgyalásokból fakadó kötelezettségek, azaz a culpa in contrahendo (igaz, ez utóbbi könnyen megítélhető, hiszen azt hatálya alól a Róma I. rendelet 1. cikk (2) bekezdésében maga is kizárja, a Róma II. rendelet pedig kifejezetten a hatálya alá vonja). ${ }^{24}$

a) A polgári és kereskedelmi ügyek is az EU önálló koncepciója, amelyet ennek megfelelően kell értelmezni. Az EUB gyakorlatának megfelelően ez azt jelenti, hogy a Róma I. rendelet nem vonatkozik a közfunkciók gyakorlásával kapcsolatos kérdésekre (pl. C-29/76. sz. Eurocontrol-ítélet, C-172/91. sz. Sonntag-ítélet, C-154/11. sz. Mahamdia-ítélet). ${ }^{25}$ A rendelet külön nevesíti, hogy nem alkalmazható különösen az adó-, vám- és közigazgatási ügyekre [1. cikk '(1) bekezdés].

b) Végül a rendelet elöírja a kolliziós jogi helyzet fennálltát. Ez azt jelenti, hogy a szerződéses kötelezettség különböző államok jogához kapcsolódjon. Ez megvalósulhat különböző országhoz kapcsolódó elemek meglétével, pl. eltér a szerződést kötő felek szokásos tartózkodási helye, avagy egy külföldi jog felek általi választásával, amennyiben a szerződéses kötelem kizárólag a lex forihoz kapcsolódik.

A Római I. rendelet negative felsorolja, hogy mely kérdések nem tartoznak a tárgyi hatály alá [1. cikk '(2) bekezdés], ezek a tárgyi hatály alól kizárt kérdések a következők:

${ }^{20}$ Lüttringhaus [2015], 31-33. o.

${ }^{21}$ Megjegyzendő, hogy a CESL [a végül el nem fogadott rendelettervezet a közös európai adásvételi jogról COM (2011) 635] értelmezésében is megjelenik a szerződés fogalma: „olyan megállapodás, amelynek célja kötelezettségek létrehozása vagy más joghatások kiváltása".

${ }^{22}$ Lüttringhaus [2015], 32. o.

${ }^{23}$ ECLI:EU:C:2016:40.

${ }^{24}$ Bővebben: Lüttringhaus [2015], 51-67. o

${ }^{25}$ További esetjog: Lüttringhaus [2015], 38. o. 
a) természetes személyek személyi állapotával, illetve jog- és cselekvőképességével összefüggő kérdések;

b) a családi kapcsolatokból és a hasonló joghatásúnak tekintett kapcsolatokból - beleértve a tartási kötelezettséget is - eredő kötelezettségek;

c) a házassági vagyonjogból eredő és a házasságéval hasonló joghatásúnak tekintett kapcsolatokra alkalmazandó vagyonjogi jogszabályokból, továbbá a végrendeletből és öröklésből eredö kötelezettségek;

d) váltók, csekkek és saját váltók, valamint egyéb átruházható értékpapírok alapján létrejövő kötelezettségek;

e) választottbírósági megállapodások és joghatósági kikötések;

f) a társasági jogot, valamint a más jogi személyekre vagy jogi személyiség nélküli szervezetekre vonatkozó jogot érintő kérdések (például a társaságok és más jogi személyek vagy jogi személyiség nélküli szervezetek bejegyzés útján vagy más módon történő létrehozása, jogképessége, belső szervezete és müködése vagy megszünése, valamint a társaság, illetve szervezet tagjainak és tisztviselőinek személyes felelőssége a társaság vagy a szervezet kötelezettségeiért);

g) képviselet kérdése;

h) célvagyon (,,trust”) alapítása, és az alapítók, vagyonkezelők (,,trustee”) és a kedvezményezettek közötti jogviszony;

i) szerződés megkötését megelőzően folytatott tárgyalásokból fakadó kötelezettségek (culpa in contrahendo);

j) bizonyos élet- és balesetbiztosítási szerződések.

A Róma I. rendelet tárgyi hatálya és a Brüsszel I. rendelet közötti összefüggést vizsgálta az EUB a magyar vonatkozású Höszig Kft. kontra Alstom Power Thermal Services-ügyben (C-222/15. sz.). ${ }^{26}$ A felek egymással Magyarországon legyártandó, Franciaországban lévő erőmüvekben történő beépítésre szánt fémszerkezetek elkészítésére több vállalkozási szerződést kötöttek. A magyar felperes kérelmében arra hivatkozott, hogy a szerződésekre vonatkozó ÁSZF-ben kikötött francia jog (jogválasztás) és a párizsi bíróságok kizárólagos joghatósági kikötése (fórumválasztás) nem vált a jogviszonyuk részévé. Ti. a Róma I. rendelet szerint a szerződési feltétel érvényességét illetően a fél hivatkozhat a központi ügyvezetése helyének államának jogára annak megállapítása érdekében, hogy a hozzájárulását azért nem adta meg, mert a körülményekből az tünik ki, hogy az magatartásának észszerütlen következ-

${ }^{26}$ ECLI:EU:C:2016:525. 
A nemzetközi szerződésekre alkalmazandó jog meghatározása, különös...

ménye [10. cikk (2) bekezdés]. Tulajdonképpen tehát a magyar társaság a magyar jog alapján kérte a magyar bíróságtól annak megállapítását, hogy a francia jog és fórum kikötése számára észszerủtlen lett volna, tehát a hozzájárulását azok elfogadásához nem adhatta meg. Az EUB azonban világosan rámutatott, hogy a Róma I. rendelet tárgyi hatálya nem terjed ki a joghatósági kikötésekre [1. cikk (1) bekezdés e) pont], és a Brüsszel I. rendelet szerint érvényes francia joghatósági kikötés [23. cikk (1) bekezdés] miatt a magyar bíróság nem is rendelkezik joghatósággal a jogvita elbírálására. A vitatott jogkikötés érvényességéről, amelynek értelmében a szerződésekre a francia jog alkalmazandó, majd a francia bíróságoknak a Róma I. rendelet szerint kell dönteniük.

A Róma I. rendelet elődje, a Római Egyezmény tárgyi hatályának társaságokra vonatkozó kivételét vizsgálta az EUB a KA Finanz-ítéletben (C-483/14. sz.). ${ }^{27}$ A kérdés akként merült fel, hogy mely jog alkalmazandó a határokon átnyúló beolvadással történő egyesülést követően a beolvadó társaság által kötött kölcsönszerződésre, annak értelmezésére, az abból fakadó kötelezettségek teljesítésére, valamint e szerződés megszűnésének módjaira. Az EUB deklarálta, hogy a társaságok megszünését, egyesülését vagy társulását szabályozó jogi aktusok az Egyezmény 1. cikkének (2) bekezdésében szereplö kizárás alá tartoznak, így az nem alkalmazandó a társaságok egyesülésére. Mivel azonban a vitatott kölcsönszerződés az egyesülés előtt köttetett és az a Római Egyezmény hatálya alá tartozik, arra a felek által választott német jog irányadó. E kikötött jog pedig az egyesülés után is alkalmazandó a szerződésre, annak értelmezésére, az azokból fakadó kötelezettségek teljesítésére, valamint ezek megszűnési módjaira.

\subsubsection{A Róma I. rendelet szerkezete}

Amennyiben az adott ügylet a Róma I. rendelet hatálya alá tartozik, annak rezsimje alkalmazandó, amelynek szerkezete a következő föbb részekből áll:

- az alkalmazandó jog meghatározásának szubjektív módja: a jogválasztás

- az alkalmazandó jog meghatározásának objektív módja: a jogválasztás hiányában irányadó jog

- speciális szerződésekre irányadó jog (fuvarozási, fogyasztói, biztosítási, egyéni munkaszerződések)

27 ECLI:EU:C:2016:205. 
- egyéb rendelkezések: imperatív szabályok, érvényesség, cselekvőképesség, engedményezés, beszámítás, szokásos tartózkodási hely, renvoi, közrend.

Ezen kérdések közül jelen tanulmányban csak a jogválasztás általános szabályait és korlátait vizsgálom.

2.3.3. Az alkalmazandó jog meghatározása a felek által: a jogválasztás (lex pro voluntate)

2.3.3.1. A jogválasztásról általában

A szerződést kötő felek akarati autonómiájának elismerése és lehetővé tétele, azaz hogy a felek maguk dönthetnek a jogviszonyukra alkalmazandó jogról, röviden jogválasztásnak (lex pro voluntate), az alkalmazandó jog szubjektív meghatározásának nevezzük. ${ }^{28}$ Ez az alapvető szabadság a magánautonómiának, tehát az anyagi szerződési szabadságnak a nemzetközi magánjogi megfelelője. ${ }^{29}$

A XIX. században föként Pasquale Stanislao Mancini és az olasz iskola érdeme volt a felek jogszabályválasztó jogára vonatkozó modern nézetek kidolgozása és általánossá tétele. ${ }^{30}$ Azonban a jogválasztás a XX. század első felében az egyik legvitatottabb kérdése maradt mind az elméletnek, mind a gyakorlatnak. Míg az angol, francia és német bírói gyakorlat kedvezőbb fogadtatásban részesítette a felek akarati autonómiáját, addig más államok gyakorlata ellenségesebben viszonyult a kérdéshez. A XX. század második felében azonban a szerződések körében egyre inkább elismerték, majd a kodifikált jogokban a nemzetközi szerződési jog alapintézményévé vált, gondoljunk csak az 1980-ben megszületett Római Egyezményre. ${ }^{31}$

Az Egyesült Államokban - csakúgy mint Európában - megosztott volt az elmélet és a gyakorlat. Míg a Legfelsőbb Bíróság elfogadta a felek jogválasztó jogát, addig Joseph Henry Beale, az első kollíziós jogi Restatement (Restatement of the Conflict of Laws, 1934) szerkesztője szerint az alkalmazandó jog az állami szuverenitással összefüggő kérdés, ezért túlmutat a feleken. Ennek megfelelően az első Restatement még hallgatott erről a kapcsoló elvről. ${ }^{32}$

${ }^{28}$ Burián-Czigler-Kecskés-Vörös [2010], 201. o. A magyar irodalomban egyedülállóan részletesen a jogválasztás elméletéröl: Palásti [2008].

${ }^{29}$ Mádl-Vékás [2016], 337. o.

${ }^{30}$ Uo., Burián [2014], 97. o.

${ }^{31}$ Rühl [2007], 5. o.

${ }^{32}$ Rühl [2007], 6. o. 
A nemzetközi szerződésekre alkalmazandó jog meghatározása, különös...

Napjainkra a jogválasztás szabadságát a nemzetközi kereskedelmi szerződések terén univerzálisan elismerik (kivéve egyes latin-amerikai országokat, pl. Brazília nem szabályozza - igaz, már nem is tiltja az instrumentumot; a chilei jog csak akkor ismeri el jogválasztást, amennyiben az alkalmazandó jog megegyezik a chilei joggal). Nem csak az elöreláthatóság miatt elönyös, ha a felek a lehető legnagyobb szabadságot élvezik az alkalmazandó jog megválasztása tekintetében, hanem a jogválasztás szabadsága a szabad kereskedelemnek is fontos garanciája, így a szabad versenyen alapuló piacgazdaság müködésének egyik biztosítéka is. Mivel a felek rendszerint olyan anyagi jogot választanak, amelynek jogintézményeit ismerik, rendelkezéseivel tisztában vannak, ezáltal az előreláthatóság mellett a jogbiztonság szempontjai is érvényre jutnak. ${ }^{33}$ Mindemellett a jogalkalmazó számára is kedvező a jogválasztás, hiszen ezáltal leegyszerűsödik a szerződésre alkalmazandó jog kiválasztásának néha bizony igencsak bonyolult processzusa. Megjegyzendő, hogy az utóbbi években a jogválasztás a nemzetközi magánjog más, a szerződések jogán kívüli területeken, így a szerződésen kívüli kötelmi viszonyokban, korlátozottan ugyan, de a házassági vagyonjogban, az öröklési jogban, valamint még a dologi jogban is elismerést nyert. Az akarati autonómia, a jogválasztás kapcsoló elve ezért mára a kollíziós jog egyik alapintézményének tekinthetö.

2.3.3.2. A jogválasztás a Róma I. rendeletben

A feleknek az alkalmazandó jog megválasztására vonatkozó szabadsága tehát a szerződéses kötelezettségekre irányadó kollíziós szabályok rendszerének egyik alapja, így a Róma I. rendeletnek is a sarokköve. A felek nemzetközi magánjog által biztosított akarati autonómiája minden esetben megelőzi a jogválasztás hiányában (azaz objektív kapcsolással) történő jog meghatározását. A jogválasztásnak tehát mindig elsőbbsége van.

A Róma I. rendelet 3. cikk (1) bekezdése deklarálja a szabad jogválasztást, amikor kimondja: „A szerződésre a felek által választott jog az irányadó.” Ez a rendelkezés tehát nagyfokú szabadságot biztosít a feleknek, ugyanakkor fontos hangsúlyozni, hogy ez nem tekinthető abszolút és korlátlan jogválasztási lehetőségnek. Ti. az uniós jogalkotó a lex voluntatis elsőbbsége mellett bizonyos esetekben korlátozza a felek akarati autonómiáját.

33 Burián [2016], 61-62. o. 
A jogválasztás Róma I. rendeletbe foglalt korlátai a következők:

- a gyengébb fél védelme miatt a személyszállítási, a fogyasztói, az egyéni munka- és a biztosítási szerződések körében [5. cikk (2) bek., 6. cikk (2) bek., 7. cikk (3) bek., 8. cikk (1) bek.];

- a tisztán egyetlen államhoz kapcsolódó szerződések és a belső piaci klauzula esetében az adott állami és az uniós jog kógens rendelkezéseinek elsőbbsége [3. cikk (3) és (4) bek.];

- az imperatív szabályok (9. cikk) és a fórum közrendjébe ütközés (21. cikk).

A Róma I. rendelet alapján a jogválasztás (lex pro voluntate) összetett szabályozása az alábbi főbb alkérdésekre bontható:

a) Anyagi jogi - kollíziós jogi jogválasztás

b) Választható jogok köre

c) Kifejezett - hallgatólagos jogválasztás

d) Jogválasztás ideje

e) Szerződés feldarabolása (dépeçage)

f) Jogválasztás további korlátai: imperatív szabályok és közrend

a) Anyagi jogi - kollíziós jogi jogválasztás. A magánautonómia egyik eleme a szerződés tartalma meghatározásának szabadsága. Ez tükröződik a nemzetközi magánjogban is, azaz a feleknek lehetőségük van arra, hogy a törvényi szabályozás diszpozitív rendelkezései helyett egy másik állam jogát választják, de ez a választás a kógens rendelkezések hatályát nem érinti. Ezt hívjuk anyagi jogi jogválasztásnak, amikor tehát a felek által választott jog a szerződésre egyébként - a jogválasztás hiányában - irányadó jog diszpozitív szabályainak helyébe lép. A felek jogválasztási szabadsága a kollíziós jogban ennél tovább is megy, ugyanis ha a szerződés több állam jogához kapcsolódik, akkor a jogválasztással a felek teljes egészében, a kógens szabályokra vonatkozóan is kivonhatják szerződésüket az egyébként - a jogválasztás hiányában - irányadó jognak a hatálya alól. Ezt kolliziós jogi jogválasztásnak nevezzük, amikor tehát a felek által választott jog teljes egészében (azaz kógens és diszpozitív szabályaival együtt) az egyébként - a jogválasztás hiányában - irányadó jog helyébe lép.

Érdemes felhívni a figyelmet arra, hogy a jogválasztás - a jogtudomány többségi álláspontja, a tételes jog és a gyakorlat szerint - nem terjeszthető ki a kikötött jog kollíziós jogi szabályaira (azaz jogválasztással a kollíziós szabályokat a felek nem választják meg). Amennyiben a jogválasztás kiterjedne az anyagi jogon túl a kol- 
A nemzetközi szerződésekre alkalmazandó jog meghatározása, különös...

líziós jogra is, az tulajdonképpen a jogintézmény célját és értelmét ásná alá. Ebből következik az is, hogy jogválasztás esetén kizárt a vissza- és továbbutalás (renvoi).

Míg a XX. sz. közepén a jogtudósok többsége (pl. hazánkban Szászy István) ${ }^{34}$ azon álláspontot képviselte, hogy a szerződésre kikötött jog nem függetleníthető teljesen a szerződésre objektíve - azaz jogválasztás hiányában - alkalmazandó jogtól, tehát a jogválasztás csak anyagi jogi jogválasztás lehet, ${ }^{35}$ napjainkra a jogválasztó jog kiteljesedett, egyértelmúvé vált a kolliziós jogi jogválasztás fószabálya. Egy példával élve: egy osztrák megrendelő és egy magyar vállalkozó vállalkozási szerződésében a német jog kikötése azt jelenti, hogy a német anyagi jog (kógens és diszpozitív szabályaival együtt) kiszorítja az egyébként alkalmazandó (magyar) jog rendelkezéseit.

A kezdetben a bíróságok követte főszabályt tehát átvette a tételes jog is, így mind a Római Egyezmény, mind a Róma I. rendelet ekként a jogválasztásra kollíziós jogi jogválasztásként tekint.

Bizonyos szűk területen azonban megmaradt az anyagi jogi jogválasztás. A Róma I. rendelet kifejezett rendelkezései alapján ezek a következőek:

- tisztán egyetlen államhoz kapcsolódó szerződések [3. cikk (3) bek.];

- belső piaci klauzula [3. cikk (4) bek.];

- fogyasztói szerződések [6. cikk (2) bek.];

- egyéni munkaszerződések [8. cikk (1) bek.].

E helyütt a jogválasztás föszabályánál megjelenő két rendelkezéssel: a tisztán egyetlen államhoz kapcsolódó szerzödések és a belsö piaci klauzula esetével foglalkozunk.

A tisztán egyetlen államhoz kapcsolódó szerződések és a belső piaci klauzula kodifikálásának célja tulajdonképpen a nemzetközi magánjogban csalárd kapcsolásnak nevezett szituációk megelözése. A jogválasztás korlátozásával az uniós jogalkotó a kollíziós kapcsolás manipulálásának, azaz a felek alkalmazandó jog megkerülésére irányuló magatartásának kívánt gátat szabni.

A tisztán egyetlen államhoz kapcsolódó szerzödésekre a Róma I. rendelet 3. cikk (3) bekezdése irányadó, e szerint: „[a]mennyiben a jogválasztás időpontjában valamennyi, a jogviszonyra vonatkozó egyéb lényeges tényállási elem más országhoz kapcsolódik, mint amelynek jogát választották, a felek választása nem sértheti a másik állam azon jogszabályi rendelkezéseinek alkalmazását, amelyektől megállapodás útján nem lehet eltérni." Ennek értelmében, ha a szerződés kizárólag egyetlen

${ }^{34}$ Szászy [1929].

${ }^{35}$ Palásti [2008], 15-16, 57-58. 
államhoz kapcsolódik, a felek élhetnek ugyan egy másik állam jogának megválasztásával, de csak anyagi jogi értelemben, azaz az egyébként irányadó jog azon szabályai, amelyektől „megállapodás útján nem lehet eltérni”, tehát kógensek, elsőbbséget élveznek a választott joggal szemben. Példának okáért a Róma I. rendelet szerint tisztán belföldi szerződésnek minősülne az az eset, amikor két, Magyarországon bejegyzett és itt központi ügyvezetési hellyel rendelkező társaság között, egy Magyarországon felépítendö üzletház kivitelezésére kötik ki a felek a német jogot. Ennek mögöttes indoka pedig az, hogy a megrendelö magyar társaságnak két német állampolgár a tulajdonosa. Azt azonban tudjuk, hogy a társaságok honosságát (személyes jogát) a társaság tulajdonosainak személyes joga nem befolyásolja, tehát nemzetközi magánjogi értelemben ez nem merül fel a szerződéses jogviszonyban mint releváns külföldi elem. Jelen vállalkozási szerződés tehát tisztán belföldi szerződésnek tekinthető, így bár választható, de csak a magyar jog diszpozitív szabályainak körében érvényesülhet a német jog.

A bírói gyakorlatban merült fel, hogy mi tekinthető releváns külföldi elemnek. Rendszerint lényeges elem a felek szokásos tartózkodási helye, vagy központi ügyvezetési helye, a szerződéskötés és a teljesítés helye (amennyiben ez a hely nem fiktív, hanem tényleges kapcsolatban van a szerződés valódi tartalmával), avagy ha a szerződés tárgyát képező dolog külföldön fekszik. Ezzel ellentétben a felek eltérő állampolgársága nem releváns. ${ }^{36}$

Hasonló esetet jelenít meg uniós kontextusban a belső piaci klauzula. A Róma I. rendelet 3. cikk (4) bekezdése kimondja: „[a]mennyiben a jogválasztás időpontjában valamennyi egyéb lényeges tényállási elem egy vagy több tagállamhoz kapcsolódik, a felek valamely nem tagállam jogára vonatkozó jogválasztása nem sértheti a közösségi jog - illetve adott esetben az eljáró bíróság szerinti tagállam jogában végrehajtott - olyan rendelkezéseinek alkalmazását, amelyektől megállapodás útján nem lehet eltérni." Ez a rendelkezés tehát a közösségi, ma úgy mondjuk: uniós jog csalárd kikerülését hivatott megakadályozni. Tehát ha a jogválasztás időpontjában minden lényeges tényállási elem egy vagy több tagállamhoz kapcsolódik, akkor a felek nem tagállami jogra irányuló választása esetén is alkalmazandóak az uniós jog kógens rendelkezései. Ez az anyagi jogi jogválasztásról szóló korlátozás tisztán uniós jogviszonyban, azaz kizárólag csak az EU területéhez kapcsolódás esetén merül fel (itt az EU területe alatt kell érteni Dániát is; a kógens szabályok körébe pedig a „,tagállam jogában végrehajtott" kifejezés szerint egyértelmúen beletartoznak az irányelvek).

${ }^{36}$ Ragno [2015], 111-113. o. 
A nemzetközi szerződésekre alkalmazandó jog meghatározása, különös...

b) Választható jogok köre. A Róma I. rendelet 3. cikk (1) bekezdésében lévő „felek által választott jog” kifejezés egy állam jogának választását teszi lehetővé. Előfordul, hogy a különböző államban szokásos tartózkodási hellyel vagy központi ügyvezetési hellyel rendelkező felek egy neutrális (semleges) harmadik állam jogát kötik ki a szerződésükre irányadó anyagi jogként.

A (13) preambulum-bekezdésben azonban hozzáteszi, hogy a rendelet nem zárja ki, hogy a felek nem állami joganyagra vagy nemzetközi egyezményre történő hivatkozást építsenek be a szerződésbe. Következésképp valamely elismert jogrendszer alá nem sorolható, ún. nem állami jogok, mint a lex mercatoria („,kereskedők joga”), valamint a különböző Alapelvek (UNIDROIT Kereskedelmi Szerződések Alapelvei, vagy az Európai Szerződési Jogi Alapelvek), vagy nemzetközi egyezmények, mint pl. a Bécsi Vételi Egyezmény kikötése a szerződésben anyagi jogi jogválasztásként értelmezhető. ${ }^{37}$ Hasonló a helyzet a vallási jogok, vagy az olyan nemzetközi feltételek kikötése esetén is, mint pl. az INCOTERMS vagy más szokvány gyüjtemények.

Megjegyzendő, hogy kollíziós jogi jogválasztásként ezen nem állami jogeszközök választottbíróságok elött, illetve rendes bíróságok elött csak a Róma I. rendelet (és a Római Egyezmény) hatályán kívül eső szerződésekre alkalmazhatók, amenynyiben persze azt a vonatkozó kollíziós szabály lehetővé teszi. (A magyar Kódex és az új nemzetközi magánjogitörvény-tervezet - bár kifejezetten nem deklarálja, de - szintén csak egy állam jogának választását teszi lehetővé.)

A rendelet megalkotásának időpontjában a Bizottságban intenzív munka folyt a közösségi anyagi szerződési jog egységesitését illetően. Ennek megfelelően a (14) preambulum-bekezdésben foglalt értelmező rendelkezésben szerették volna biztosítani ennek az új rendeletnek a választhatóságát, e szerint ha az unió: „egy megfelelő jogi eszközben az anyagi szerződési jogra vonatkozó szabályokat fogadna el [...] ez a jogi eszköz lehetővé teheti a felek számára, hogy e szabályok alkalmazását válasszák". Az adásvételi szerződések anyagi jogi szabályozási rezsimjét egységesítő, ún. Közös Európai Adásvételi Jogról szóló (Common European Sales Law - CESL) 2011-ben közzétett rendelettervezet elfogadása azonban (a tagállamok közötti konszenzus hiánya miatt) végül lekerült a napirendről. Tehát ilyen jogeszközröl jelenleg nem beszélhetünk.

A Róma I. rendelet szabályaiból levezethető, hogy nem választható olyan állam joga, amely állam már nem létezik (pl. római jog, szovjet jog). Ezen túlmenően nincs negatív jogválasztás sem, tehát nem zárható ki egy vagy több állam jogának

${ }^{37}$ Részletesen: Palásti [2005]; van Calster [2016], 213. 
alkalmazása a szerződésre. Amennyiben ilyen kikötéseket találna a fórum, akkor a jogválasztás hiányában irányadó szabályokat kell alkalmaznia. ${ }^{38}$

Kezdetben kétséges volt az olyan esetek megítélése, amelyekben a felek egy a jövőben akár változó, így a kikötésben még egy bizonytalan, „lebegö” jogot választanak. Ez az ún. lebegö jogválasztási klauzula (,floating” choice of law clauses) egy olyan szerződéses rendelkezés, amely az egyik fél számára egy elöre meghatározott esemény bekövetkezésekor teszi lehetővé az alkalmazandó jog megválasztását. A gyakorlatban az egyik fél (vagy egy harmadik személy) által - rendszerint egy felek által elöre meghatározott listából - történik a választás, ezek elterjedtek pl. a tengeri árukereskedelemben közismert értékpapírok, az ún. hajóselismervények (bill of lading) esetében. Ezen „lebegő” kikötéseket az angolszász fórumok a saját joguk alapján rendszerint érvénytelennek tekintik. ${ }^{39}$ A Római Egyezmény szabályai szerint azonban még az angolszász bíróságok is hajlanak az akarati autonómia szélesebb térnyerésére, pl. egy ügyben olaj tengeri fuvarozására kötöttek szerződést, és a jogválasztó klauzulában „,a lobogó joga” szerepelt. ${ }^{40}$ Azonban az árut számos, különböző lobogó alatt fuvarozó hajó szállította. Mivel a szerződés megkötésekor a felek úgy állapodtak meg, hogy az alperes maga fuvarozza az árut (francia lobogó alatt), ennélfogva a Lordok Háza akként foglalt állást, hogy ez egy kifejezett jogválasztás volt, mert a megkötés idején a klauzula a francia jogra utalt. Tekintettel arra, hogy a Róma I. rendeletben a 3. cikk (2) bekezdése lehetővé teszi, hogy a felek visszaható hatállyal a kikötött jogot módosítsák, így a lebegő jogválasztási kikötések érvényességének e szerint nincs akadálya. ${ }^{41}$

Rendszerint a jogválasztás alatt az alkalmazandó jog megválasztásának dinamikus felfogását értjük, azaz a felek az állam jogát mint dinamikusan változó anyagot, fejlődő ,jogi testet” kívánják a szerződésükre kikötni. Bár a Róma I. rendelet erről hallgat, főszabály szerint a kikötött jog később bekövetkező változásait is figyelembe kell venni. A felek rendelkezhetnek azonban úgy is, hogy a választott jogot a jogválasztás időpontjában hatályos jogra korlátozzák, ezt hívjuk a jogválasztás statikus felfogásának. Ennek érdekében ún. befagyasztó záradékot (freezing the law in time; freezing clause) alkalmaznak, pl. a felek olyan kikötése, mely szerint X állam „2017. május 1-jén hatályos joga” irányadó a szerződésre. Gyakori a hosszú távú beruházási vagy koncessziós megállapodásokban a külföldi befektető és a fo-

38 Ragno [2015], 91-92. o.

39 Ragno [2015], 92-93. o.

${ }^{40}$ Compagnie D'Armement Maritime SA v Cie Tunisienne de Navigation SA ügy. Hivatkozza: Szabó [2009].

${ }^{41}$ Ugyanígy Ragno [2015], 93. o. 
A nemzetközi szerződésekre alkalmazandó jog meghatározása, különös...

gadó állam között kikötött ún. stabilizációs klauzula, amelyben szintén, rendszerint a szerződésre alkalmazandó jog változását tiltják. Ezen klauzulák érvényességének megítélése azonban kétséges. ${ }^{42}$ Ti. ez hasonló jellegü, mint ha a felek államok feletti jogot kívánnának kikötni. Más álláspontok szerint ráadásul a kapcsoló szabály csak azt engedi meg, hogy egy olyan jogrendszert válasszanak, amely „létezik” egy konkrét államban. A legbiztosabb módja, ha az ilyen típusú szerződésekben a fogadó állam - szerződésre kedvezőtlen - jogalkotását a befektető el akarja kerülni, az, ha a szerződésben irányadó jogként egy másik állam jogát kötik ki.

c) Kifejezett - hallgatólagos jogválasztás. A Róma I. rendelet megkülönbözteti a kifejezett és a hallgatólagos jogválasztást. A bíróságnak könnyủ meghatározni a szerződésre irányadó jogot, amennyiben a felek kifejezetten megjelölik azt (kifejezett jogválasztás). Ez történhet a szerződésbe foglalt külön klauzulával, vagy az elfogadott szerződésben, avagy külön dokumentumban a szerződéshez csatolt általános szerződési feltételekben. Ez esetben tehát a felek expressis verbis egy állam jogát kötik ki, pl.: „Jelen szerződésre a magyar jog rendelkezéseit kell alkalmazni.”

Csakúgy mint a Római Egyezmény, a Róma I. rendelet sem kívánja meg, hogy a választás kifejezett legyen. A felek hallgatólagosan is megválaszthatják a szerződésre irányadó jogot (hallgatólagos jogválasztás). Következik ez abból, hogy az egyes polgári jogi rezsimek is lehetővé teszik a ráutaló magatartással való szerződéskötést. Amennyiben azonban a felek akarata nem állapítható meg egyértelmüen, akkor azok feltehető akaratára történő hivatkozás már ún. hipotetikus jogválasztásnak minősül, amely nem képezheti a hallgatólagos jogválasztás alapját, hiszen a jogválasztás mindig egy valós választást jelent.

Eltérés olvasható ki a Római Egyezmény és a Róma I. rendelet nyelvezetéből a hallgatólagos jogválasztás bizonyítottságát illetően. Míg előbbi akként fogalmaz, hogy hallgatólagos jogválasztás ,a szerződésből vagy az eset körülményeiből kellő bizonyossággal”, addig utóbbi szerint „,egyértelműen” megállapíthatónak kell lennie. Sajnálatos, hogy a Róma I. rendelet magyar fordításánál automatikusan a Római Egyezmény szövegét vették át, holott a jogtudomány álláspontja szerint a rendelet tudatosan szükebbre szabta a fogalmat, s ezzel célja szerint a bizonyitottság magasabb fokát követeli meg. ${ }^{43}$

A hallgatólagos jogválasztás faktorai: a szerződésben egy állam jogának külön szabályaira történő utalás (pl. magyar Ptk. szakaszai megjelennek a szerződésben), vagy a szerződésben egy adott állam jogában megjelenő speciális terminológia,

${ }^{42}$ Lásd pl.: Ragno [2015], 94. o.

${ }^{43}$ Bővebben: Csöndes-Nemessányi [2008]. 
vagy olyan mintaszerződések használata, amelyek egy állam jogához kapcsolódnak (pl. a Lloyds tengeri biztosítási szerződései - angol jog), vagy a korábbi üzleti kapcsolat folyamatában, illetőleg egy kapcsolódó tranzakcióban történő jogválasztás. A fórumválasztás ugyan önmagában nem jelenti a hallgatólagos jogválasztást, tehát nem érvényesül a régi tétel, miszerint ,aki bírót választ, jogot választ” (,,qui eligit iudicem, eligit ius”), azonban a Róma I. rendelet szerint a hallgatólagos jogválasztás egy faktora a felek kizárólagos (tagállami bírósági!) joghatósági megállapodása is. (Erről a Római Egyezmény nem szól.) A (12) preambulum-bekezdés szerint: „egyik tényezőként figyelembe kell venni a felek arra vonatkozó megállapodását, hogy kizárólagos joghatóságot ruháznak egy tagállam egy vagy több bíróságára a szerződés alapján felmerülő viták eldöntésére.” Ez természetesen azt jelenti, hogy egy ilyen electio fori erős, de önmagában nem elegendő elem a hallgatólagos jogválasztás egyértelmü megállapításához.

d) Jogválasztás ideje. A szerződésre alkalmazandó jog kikötésének idejéről a Róma I. rendelet (Római Egyezmény) kifejezetten nem szól. A rendelet a 3. cikk (2) bekezdésében csak azt deklarálja, hogy a felek bármikor megállapodhatnak abban, hogy a szerződést a korábban irányadó jog helyett egy másik jog rendelkezései alá vonják. Időben egymás után tehát több jog is kiköthető. Egy ilyen utólagos módosítás azonban nem érintheti a szerződés alaki érvényességét és harmadik személyek jogait. A jogválasztás módosításának időbelisége a „,bármikor” szót használja, ebből az következik, hogy a felek általi jog kikötésének első időpontját sem korlátozza a szerződéskötés időpontjára. A felek tehát tipikusan a szerződéskötéstől (bizonyos esetekben, pl. keretszerződésben akár korábban is) még a perbeli eljárásban is jogot választhatnak.

e) Szerződés feldarabolása (dépeçage). Bár a jogválasztás főszabály szerint a szerződés egészére kiterjed, de a feleknek arra is szabadságuk van, hogy azt több jog uralma alá helyezzék. A 3. cikk (1) bekezdésének utolsó mondatában a Róma I. rendelet (csakúgy, mint a Római Egyezmény) lehetővé teszi a szerződés feldarabolását: „[v]álasztásukkal a felek a szerződés egészére vagy annak csak egy részére alkalmazandó jogot határozhatják meg." Ezt a nemzetközi magánjogban dépeçage-nak nevezzük. A szerződés feldarabolására irányuló jogválasztás is lehet kifejezett vagy hallgatólagos, amennyiben ez a szerződésből és egyéb körülményekből egyértelmüen kiderül. Az esetjogban ez utóbbit fogadták el garanciára, munkavállalói jogokra kikötött klauzulák és a szerződésszegés jogkövetkezményei tekintetében. ${ }^{44}$

${ }^{44}$ Részletesen: Ragno [2015], 104-106. o. 
A nemzetközi szerződésekre alkalmazandó jog meghatározása, különös...

A dépeçage bonyolultsága miatt nagyon ritka a gyakorlatban, és alkalmazása esetén a korlátja hogy a felek jogai és kötelezettségei egyensúlyban maradjanak. ${ }^{45}$

f) Jogválasztás további korlátai: imperatív szabályok és közrend. A Róma I. rendelet újdonsága, hogy kifejezetten deklarálja az imperatív szabály fogalmát, a 9. cikk szerint ezek „olyan rendelkezések, amelyek betartását valamely ország a közérdek - mint például politikai, társadalmi vagy gazdasági rendjének megőrzése szempontjából döntő fontosságúnak ítéli, és megköveteli a hatálya alá eső valamenynyi tényállásra történő alkalmazását, függetlenül attól, hogy e rendelet a szerződésre mely jog alkalmazását írja elő".

Az alkalmazandó jog, jelen esetben a lex contractus alkalmazása tehát nem lehet abszolút. Vannak olyan, az ország közérdeke, így például politikai, társadalmi vagy gazdasági rendjének megőrzése szempontjából fontos rendelkezések, amelyek alkalmazása imperatív, azaz feltétlen jellegü. Ez azonban csak kivételes lehet. Tipikusan ilyenek a közigazgatási jogi, pénzügyi jog vagy versenyjogi szabályok. A szerződési jog területén gyakoriak pl. az engedélyezési elöírások, a behozatali/kiviteli tilalmak (pl. a fenti tenyésztojás adásvételénél megjelenő madárinfluenza esetében; avagy a kulturális javak tekintetében), vagy az embargós rendelkezések. A német bíróság egy ügyben pl. imperatívnak tekintette a hazai építészek és mérnökök díjazására vonatkozó szabályozást. ${ }^{46}$ Vitatott a gyakorlatban a fogyasztóvédelmi szabályok helyzete, azok imperatív vagy kógens voltát illetően. Főszabályként meggyőzőnek tűnik az az álláspont, hogy ha a rendelkezés közérdeket is szolgál, akkor imperatív szabálynak tekinthető. Amennyiben ellenben a szabály fó célja az egyedi fogyasztó védelme, akkor a feltétlen alkalmazás nem illeti meg. ${ }^{47} \mathrm{~A}$ lex fori imperatív szabályai tehát elsőbbséget élveznek a lex causae-val, sőt még annak imperatív szabályaival szemben is.

Az EUB az Unamar-ügyben (C-184/12. sz.) értelmezte egy imperatív jellegűnek minősített uniós irányelv (önálló vállalkozóként működő kereskedelmi ügynökökre vonatkozó 86/653/EGK tanácsi irányelv) és az ezeket átültető két tagállami jog - a szerződésben választott és a lex fori - imperatív szabályainak ütközését a Római Egyezmény 7. cikke alapján. ${ }^{48}$ Döntésében az EUB leszögezte, hogy a kereskedelmi ügynöki szerződésben kikötött tagállami jog alkalmazásától a fórum jogának imperatív voltára történő hivatkozással valamely más tagállam fóruma kizárólag akkor

45 Bővebben: Palásti [2006].

${ }^{46}$ BGH 2003.02.27., VII ZR 169/02.

${ }^{47}$ Schwartze [2017].

${ }^{48}$ ECLI:EU:C:2013:663. 
tekinthet el, ha részletesen kifejtve megállapítja, hogy a saját jogalkotója az érintett jogrend vonatkozásában alapvetőnek ítéli, hogy olyan védelmet biztosítson a kereskedelmi ügynökök számára, amely túlmegy az említett irányelv által megkövetelt mértéken, különös tekintettel ezen imperatív rendelkezések jellegére és tárgyára.

A fórum esetenként ugyanakkor a lex forihoz és a lex causae-hoz sem tartozó, ún. harmadik államok feltétlenül alkalmazandó rendelkezéseit s figyelembe veheti, amennyiben a tényállással azzal szoros kapcsolatban van. A Róma I. rendelet szerint ez azon ország jogának imperatív rendelkezései lehetnek, amelyben a szerződésből eredő kötelezettségeket teljesíteni kell vagy teljesítették, amennyiben ezek az imperatív rendelkezések a szerződés teljesítését jogszerütlenné teszik (9. cikk (3) bekezdés). Alkalmazásuk előtt viszont alapos mérlegelés szükséges: figyelembe kell venni természetüket és céljukat, és alkalmazásuk vagy nem alkalmazásuk következményeit.

A fentebb említett Nikiforidis-ügyben (C-135/15. sz. ügy) az EUB értelmezte e passzusokat. E szerint az eljáró bíróság nem alkalmazhat olyan imperatív rendelkezéseket, amelyek nem az eljáró bíróság helye szerinti állam vagy azon állam rendelkezései, amelyben a szerződésből eredő kötelezettségeket teljesíteni kell vagy azokat teljesítették. Ugyanakkor a bíróság ezen imperatív rendelkezéseket ténybeli elemként figyelembe veheti, amennyiben ezt a rendelet szerint a szerződésre irányadó jog elöírja. Nikiforidis 1996-tól kezdve egy Nürnbergben található és a Görög Köztársaság által fenntartott általános iskola alkalmazásában állt mint tanár. A 2010 októbere és 2012 decembere közötti időszak folyamán a Görög Köztársaság jelentősen csökkentette Nikiforidis korábban a munkaszerződésekre vonatkozó német jog alapján számított bruttó díjazását, azzal az indokkal, hogy a görög jogalkotó elfogadta azt a két törvényt, amely a görög gazdasági válság orvoslására Görögország a Görög Köztársaság Európai Bizottsággal, az Európai Központi Bankkal és a Nemzetközi Valutaalappal kötött megállapodásainak a végrehajtását célozták, és a Görög Köztársaság közszférájában dolgozó valamennyi alkalmazott illetményét csökkenti, függetlenül attól, hogy ezen alkalmazottak Görögország területén vagy külföldön látják el feladataikat. Nikiforidis a 2010 októbere és 2012 decembere közötti időszakra vonatkozó további díjazás, valamint bérelszámolás iránt indított eljárást a német szövetségi munkaügyi bíróság előtt. A Görög Köztársaság állami immunitásra alapított joghatósági kifogását a német fórum elutasította, mert az ügy tárgyát képező munkaviszony magánjogi természetü. Továbbá a bíróság megállapította, hogy a két törvény irányadó rendelkezései a nemzetközi magánjog értelmében imperatív rendelkezéseknek tekinthetőek. E görög szabályok viszont ellentétesek azzal a német 
A nemzetközi szerződésekre alkalmazandó jog meghatározása, különös...

jogi előírással, hogy kétoldalú vagy egyoldalú szerződésmódosítás hiányában a díjazás ilyen csökkentése nem lehetséges. A fórum által EUB elé utalt kérdés az volt, hogy a Róma I. rendelet 9. cikkének (3) bekezdését megszoritóan kell-e értelmezni, ezáltal kizárólag az eljáró bíróság helye szerinti állam vagy a szerződés teljesítésének helye szerinti állam imperatív rendelkezéseire lehet hivatkozni, avagy közvetve, más tagállam imperatív rendelkezései is figyelembe vehetők. Mivel azonban a Róma I. rendelet 9. cikkének rendelkezéseit szigorúan kell értelmezni, és Nikiforidis munkaszerződését Németországban teljesítették, valamint a fórum német, így a görög imperatív rendelkezések közvetlenül vagy közvetve sem alkalmazhatóak (azonban az EUB szerint a fórum ténybeli elemként ezeket figyelembe veheti).

A Róma I. rendelet a közrend védelmére szolgáló másik eszközről is szól, a közrendi klauzuláról. A 21. cikk szerint: „,[a]z e rendelet által meghatározott jog valamely rendelkezésének alkalmazása csak akkor tagadható meg, ha az alkalmazás nyilvánvalóan összeegyeztethetetlen az eljáró bíróság országának közrendjével (ordre public)." A közrendi záradék generálklauzulaként a fórum jogrendszerének „kemény magját” védi. ${ }^{49} \mathrm{Az}$ imperatív normák és a közrendi záradék tehát a különös-általános viszonyában állnak egymással. A közrendi záradék is csak kivételesen alkalmazandó eszköz, amelyet csak végső esetben szabad igénybe venni, akkor ha a külföldi jog alkalmazása nyilvánvalóan összeegyeztethetetlen lenne az eljáró bíróság országának közrendjével. Továbbá fontos elem az is, hogy a konkrét tényállás szoros, érdemi kapcsolatban álljon a fórum jogrendjével.

2.3.3.3. A Kódex és az új törvénytervezet szabályai a jogválasztásról

Elsőként meg kell jegyezni, hogy a hazai, belső nemzetközi magánjogi szabályok a nemzetközi szerződési jog területén csak igen szűk, az uniós rendelet és a Római Egyezmény által nem szabályozott körben, vagy azok időbeli hatálya elött kötött szerzödések esetében lesznek alkalmazandók.

Az újonnan születő, jelenleg az Országgyülés elött lévö nemzetközi magánjogi törvénytervezet ${ }^{50}$ számos újitást hoz a Kódex szabályozásához képest, amely utóbbi csak a kifejezett és hallgatólagos jogválasztásról és a dépeçage-ról rendelkezik. A jogválasztással kapcsolatosan kiemelendő fejlemény, hogy az általános szabályok

${ }^{49}$ Mádl-Vékás [2016], 149. o.

${ }^{50} \mathrm{~T} / 14237$. sz. javaslat a nemzetközi magánjogról. Letölthető: http://www.parlament.hu/ irom40/14237/14237.pdf 
között rendelkezik a törvénytervezet a „közös”, azaz a joganyagon végigfutó, alkalmazandó jog kikötésével kapcsolatos ,általánosítható” kérdésekről.

A tervezet a 9. §-ban szól:

a) a jogválasztás fószabályként kifejezett módjáról;

b) a jogválasztásról szóló megállapodás létrejöttéről és érvényességéről, amely jogviszonyra alkalmazandó jog; valamint arról, hogy

c) a jogválasztás harmadik személyek szerzett jogait nem sértheti.

Az általános részi kiemelés ugyan üdvözlendő, hiszen valóban „kifejezésre juttatja, hogy a jogválasztás a 21. században már nem egy kivételes, csak egyes jogterületeken érvényesülö módja az alkalmazandó jog meghatározásának, hanem a nemzetközi magánjog egyik alapintézménye". ${ }^{51}$ Véleményem szerint az a) pontban foglalt rendelkezés ellenben - bár vitathatatlanul a törvény szövegének ,egyszerüsítésére” szolgál a felesleges ismétlések ,kiiktatásával” - mind elméleti, mind didaktikai szempontból inkább nehézségeket okoz azáltal, hogy a jogválasztás alatt föszabályként csak annak kifejezett módját érti. Ti. egy modernnek mondott törvény ezáltal a jogintézmény indokolatlan (és a tudomány, valamint a gyakorlat által rég meghaladott) korlátozásának látszatát kelti. Holott valójában csak arról van szó, hogy az egyre szélesebb teret nyerő jogválasztás kapcsolóelve a kötelmi jog terrénumáról „kilépve” számszerűen több olyan területen nyer alkalmazást (pl. házassági vagyonjog, dologi jog, értékpapírjog), ahol a jogalkotó bár megengedi, de kellően óvatosan - és helyesen - a kifejezett módra korlátozza a felek akarati autonómiáját. Azon újabb kollíziós jogi kodifikációk, amelyek a jogválasztást kiemelten a joganyag elején szabályozzák, a kifejezett és hallgatólagos módot is „,alapesetként” deklarálják, lásd pl. a 2011-ben hatályba lépett lengyel [nemzetközi magánjogi törvény 4. cikk (2) bekezdés], vagy a 2012-ben hatályba lépett holland [Ptk. nemzetközi magánjogi könyve 10:10. cikk] szabályt.

A törvénytervezet 50. $\S$-a a lex contractus-ra vonatkozóan a jogválasztásnál a Kódexnél jóval részletesebben a következőkről rendelkezik:

a) annak kifejezett vagy hallgatólagos módja: utóbbi esetében ,annak a szerződés rendelkezéseiből vagy az ügy körülményeiből egyértelmüen megállapíthatónak kell lennie"; amely így helyesen a Róma I. rendelet szükebb fogalmát veszi át;

b) szerződés feldarabolása (dépeçage);

${ }^{51}$ Burián [2017]. 
A nemzetközi szerződésekre alkalmazandó jog meghatározása, különös...

c) jogválasztás ideje: legkésőbbi időpontot illetően deklarálja, hogy arra „,a perfelvétel lezárását megelőzően, a bíróság által meghatározott határidő lejártáig van lehetőség"; összhangban az új Polgári Perrendtartás szabályaival;

d) a választott jog módosításáról;

e) kizárólag anyagi jogi jogválasztás lehetősége az egyetlen ország jogához kapcsolódó szerződések esetében; a csalárd kapcsolás kiküszöbölésére.

Bár kifejezetten nem szól róla, de a magyar Kódex és az új nemzetközi magánjogitörvény-tervezete is egy állam jogának választását teszi lehetővé. Hozzá kell tennünk, hogy az olyan homályos kikötések, mint pl. egy kölcsönszerződésre „általában az osztrák jog" választása nem elfogadható, ${ }^{52}$ de indokolatlanul korlátozni sem lehet a felek akarati autonómiáját. A Fővárosi Ítélőtábla nem fogadta el jogválasztásnak a felek azon kitételét, miszerint „a szerződésben nem szabályozott kérdésekben a Ptk. vonatkozó rendelkezései az irányadók". ${ }^{53}$ Az indoklás szerint a Kódex nem egy meghatározott jogszabálynak, hanem egy konkrétan megjelölt állam jogának megválasztására biztosít lehetőséget. Nyilvánvalóan azonban a magyar Ptk. is egy állam (Magyarország) joga. A különbségtétel az állami és nem állami jogra (ahogy fentebb láttuk, vallási jogra vagy magáninstrumentumokra) vonatkozik.

\section{3. Összegző gondolatok}

Sommásan elmondható, hogy a jogforrások egymáshoz való viszonyát, ezzel összefüggésben a Róma I. rendelet alkalmazási körét, valamint a jogválasztás korlátait az EUB gyakorlata folyamatosan értelmezi, finomítja, egyben összehangolja a kapcsolódó Brüsszel I. bis és Róma II. rendeletekkel.

Másfelől az új nemzetközi magánjogitörvény-tervezet jobban összhangba hozza a belső kollíziós szabályokat az esetek többségében alkalmazandó Róma I. rendelettel, amely bizonyosan jelentős segítséget jelent majd a hazai jogalkalmazóknak.

\section{Felhasznált irodalom}

Bánrévy Gábor [2016]: A nemzetközi gazdasági kapcsolatok joga (9. javított kiadás). Budapest, SzIT. Burián László [1992a]: Az Európai Közösségek egyezménye a szerződéses kötelmekre alkalmazandó jogról - I. rész. Külgazdaság, 36. évf. 3. sz.

${ }^{52}$ Legfelsőbb Bíróság Pf. I.25.615/2002/11.

${ }^{53}$ Pf.6.20.577/2005/4. 
Burián László [1992b]: Az Európai Közösségek egyezménye a szerződéses kötelmekre alkalmazandó jogról - II. rész. Külgazdaság, 36. évf., 5. sz.

Burián László [2008]: A Római Egyezmény alkalmazásának elméleti és gyakorlati kérdései, valamint az Egyezmény várható reformja. Közjegyzők Közlönye, 55. évf., 3. sz.

Burián László [2014]: Nemzetközi magánjog - Általános rész. Budapest, Pázmány Press.

Burián László [2016]: A jogrendszerek versenye és a nemzetközi magánjog. Iustum Aequum Salutare, 3. sz.

Burián László [2017]: A jogválasztás az új nemzetközi magánjogi törvényjavaslatban. Kézirat. [m.a.]

Burián László - Czigler Dezső Tamás - Kecskés László - Vörös Imre [2010]: Európai és magyar nemzetközi kollíziós magánjog. Krim Bt., Budapest.

van Calster, G. [2016]: European Private International Law. Second Edition, Hart Publishing.

Czigler Dezső Tamás [2009a]: A szerződésekre alkalmazandó jog jövőbeni meghatározása az Európai Közösségben: a Róma I. rendelet szabályai. Állam- és jogtudomány, 50. évf., 1. sz.

Czigler Dezső Tamás [2009b]: A szerződésekre alkalmazandó jogról szóló Róma I. rendelet a praktikum tükrében. Külgazdaság, 53. évf., 9-10. sz.

Csöndes Mónika - Nemessányi Zoltán [2008]: Jogválasztás a Római Egyezménytől a Római I. rendelet tervezetéig. Jogtudományi Közlöny, 63. évf., 5. sz.

Glavanits Judit [2016]: A Bécsi Vételi Egyezmény hazai és nemzetközi joggyakorlata - egy empirikus kutatás első részeredményei. In: Glavanits J. - Horváthy B. - Knapp L.: Az európai jog és a nemzetközi magánjog aktuális kérdései. Ünnepi tanulmányok a 65 éves Milassin László tiszteletére. SZE DFÁJK Nemzetközi Köz- és Magánjogi Tanszéke, Győr, 65-82. o.

Herzog, P. E. [1992]: Constitutional Limits on Choice of Law. Recueil des cours, 243. kötet.

Lüttringhaus, J. D. [2015]: Article 1. In: Ferrari, F. (ed.): Rome I Regulation. Pocket Commentary. SELP.

Mádl Ferenc - Vékás Lajos [2016]: Nemzetközi magánjog és nemzetközi gazdasági kapcsolatok joga. ELTE Eötvös Kiadó, Budapest.

Omlor, S. [2015]: Article 28. In: Ferrari, F. (ed.): Rome I Regulation. Pocket Commentary. SELP.

Palásti Gábor Péter [2008]: A szerződésekre alkalmazandó jog felek általi megválasztása (a jogválasztás). PhD-értekezés, Miskolc, kézirat.

Palásti Gábor [2006]: Dépecage és tronc commune a nemzetközi magánjogban. Jogtudományi Közlöny, 61. évf., 3. sz.

Palásti Gábor [2005]: Lex mercatoria, a nemzetközi jog elvei és hasonló kikötések a jogválasztó klauzulában. Külgazdaság, 49. évf., 11-12. sz.

Ragno, F. [2015]: Articles 2, 3. In: Ferrari, F. (ed.): Rome I Regulation. Pocket Commentary. SELP.

Rühl, G. [2007]: Party Autonomy in the Private International Law of Contracts: Transatlantic Convergence and Economic Efficiency. CLPE Research Paper, Nr. 4.

Schmidt-Kessel, M. [2015]: Article 9. In: Ferrari, F. (ed.): Rome I Regulation. Pocket Commentary. SELP.

Schwartze, A. [2017]: Art. 9 Rome I Regulation. In: Unalex Compendium. COM-1292 (Stand 27.02.2017)

Szabó Sarolta [2014]: A Bécsi Vételi Egyezmény mint nemzetközi lingua franca. Az egységes értelmezés és alkalmazás újabb irányai és eredményei. Budapest, Pázmány Press.

Szabó Sarolta [2009]: A Római Egyezmény egyes rendelkezéseinek megjelenése a tagállami bíróságok gyakorlatában. Jogtudományi Közlöny, 64. évf., 3. sz.

Szászy István [1929]: A szerződő felek jogszabályválasztó joga a nemzetközi kötelmi jogban. Budapest.

Vadász Vanda [2017]: Szemelvény a Bécsi Vételi Egyezmény alkalmazása köréből - tekintettel a magyar bíróságok legújabb esetjogára. Külgazdaság Jogi Melléklet, 1-2. sz.

Vékás Lajos [2009]: A nemzetközi magánjogi törvény módosításáról. Magyar Jog, 6. sz. 